\title{
The Effect of Corporate Tax
} Avoidance on the Level of Corporate Cash Holdings: Evidence from

\section{Indonesian Public Listed Companies}

\author{
Muhammad Irham Kurniawan ${ }^{1}$ and Siti Nuryanah ${ }^{2}$
}

\begin{abstract}
This study aims to examine the effect of corporate tax avoidance to the corporate cash holdings. Recent tax avoidance research found that tax avoidance is able to facilitate managerial rent extraction in the form of transfer of resources owned by the company. This study attempts to test how the relationship of tax avoidance with the amount of cash held by the company. The sample consists of 46 non-financial, non-property, non-real estate and non-construction companies from 2009-2016, with a total 368 observations. The study uses two different cash holdings measures to test the robustness of the research results. This study cannot find evidence that tax avoidance have a significant relationship to the level of cash holdings in public companies in Indonesia. Both measurements of cash holdings gave the same conclusions to the results of the study. This study provides an insight that agency theory in the context of tax avoidance and corporate cash holdings in developing countries such as Indonesia needs to be explored further as the agency conflict in Indonesia as a developing country is more principal-principal conflicts. ${ }^{3}$
\end{abstract}

JEL Classification: M40, M48, K34, K42.

Keywords: Tax avoidance, cash holdings, corporate finance.

\footnotetext{
${ }^{1}$ Universitas Indonesia, Indonesia.

${ }^{2}$ Universitas Indonesia, Indonesia.

${ }^{3}$ This paper was presented in the 6th International Accounting Conference, 27-29 August 2017. The authors thank to the anonymous reviewers and the audience of the Conference for the constructive feedback. 2 . The authors are grateful to Lukman Edwindra who has provided a source of data for this research.
} 
Kurniawan \& Nuryanah | The Effect of Corporate Tax Avoidance on the Level of Corporate Cash Holdings

\section{Introduction}

Tax avoidance within a company is all activities done by a company that results in a reduction of corporate taxes (Dyreng et al. 2008). OECD (Organization for Economic Co-operation and Development) describes that tax avoidance is a taxpayer's effort to reduce tax payable, even though this attempt may not be in violation of the law, but in fact it is contrary to the purpose of tax legislation. For the reason of tax avoidance is an act that is not against the law, it is then utilised by all taxpayers including corporate taxpayers, that as a human is rational and opportunistic, to minimise tax expenses. Moreover, big companies that are go public are more focused on the interests of shareholders than they have to pay taxes. While it is argued that tax avoidance practices can make tax paid by the company to be smaller, and hence it will maximise shareholder value (Hanlon and Heitzman, 2010), this practice can be harmful as it increases the tax risk of the company.

Most recent literature found that traditional theory of tax avoidance arguing that tax avoidance as value maximisation for shareholders is not empirically proven (Santana and Rezende 2016; Chen et al. 2014). More corporate managers are found not to act as good agents because they can take advantage from tax avoidance activities for their personal gains. These tax avoidance practices which were originally regarded as a value-adding tool for shareholders provide an opportunity for managers as the control holder of the company to take the company's resources through various attempts in long periods (Kim et al. 2010). If it is associated with the company's cash holdings, it will be highly correlated, since cash is a very liquid asset type so that it will be very easily converted by managers for personal gains (Myers \& Rajan 1998). This is found by Dhaliwal et al. (2011) that there is a negative relationship between corporate tax avoidance activities and level of cash owned by the company.

Basically, from the side of the company, there are three motives of cash holdings (Keynes 1936) which are speculative motive, transaction motive, and precautionary motive. In this case, in regards to the results of research Dhaliwal et al. (2011), the amount of company's cash holdings could endanger the activities of the company and the interests of the owners of the company due to potential cash transferred by agent of the company's: manager. Having this background, the purpose of this study is to examine how is the effect of tax avoidance on the level of cash held by public companies in the case study of Indonesia. Following Dhaliwal et al. (2011), this study examines the relationship between tax avoidance and corporate cash level in the context of a developing country i.e. Indonesia. This study extends the previous study in Indonesia conducted by Melinda (2013) that found a non-significant relationship between tax avoidance with the level of corporate cash holdings. Compared to the current study, the study of Melinda is only based on one period (cross section) data analysis. This current study is based on more sophisticated panel data collected from periods of 2009-2016. Moreover, this study tests the resilience of the literature in the case of the robustness of the results as it uses two proxies of cash holdings which are mostly used by previous studies. Following the introduction, literature review will be discussed in the next section. Research methodology then is presented followed by analysis of results and discussions. Finally, conclusions are drawn in the last section. 


\section{Literature Review and Hypothesis Development}

\subsection{Agency Theory and Tax Avoidance}

In the context of modern corporations, where there is separation between agent (management) and principals (owners), it is argued that the agent does not always act and perform its duties in the best interests of owners. Due to the asymmetric information between agent and principals, tax avoidance activities, in this case, can be used as a tool to facilitate the opportunistic behaviour of managers which at the end increasing costs borne by the owners (Dhaliwal et al. 2011).

Tax avoidance as part of tax planning can be differentiated from tax evasion, that in contrast to tax evasion, tax avoidance is conducted without violating the prevailing laws and regulations. Nevertheless, tax avoidance is such controversial activities as while a company as a taxpayer may have right to reduce the tax burden in accordance with the law, but such action is deliberately arranged and planned to minimise tax payable which at the end can be defined as illegal acts as conflicting with the law spirit (Avi-Yonah 2008; Prebble and Prebble 2010). The tax avoidance behavior undertaken by a firm provides marginal benefits and marginal costs (Chen et al. 2010). Companies should be careful in analysing and considering every action taken, including tax management through tax avoidance.

The benefits that can be obtained by the company through tax avoidance are a significant tax savings of which can be transferred to owners of the company. With the action of tax savings, the tax burden paid becomes smaller so that the net income of the company becomes larger. Managers can also get benefit from the tax avoidance activities which is a higher compensation or bonus since they are perform well minimising the tax burden paid by the company, thus benefiting the owners of companies with greater profit as well. nevertheless, managers can do rent extraction too. This is an action which the managers undertake to prioritise and maximise his personal interests, not the interests of the company owners. Measures taken by managers such as the preparation of aggressive financial statements, transactions with privileged parties, or taking resources or assets of the company to meet personal interests (Chen et al., 2010).

While providing marginal benefits, tax avoidance behaviour has some costs that may be borne by the company. The company may get tax penalties imposed on tax fraud, and may affect the fall in stock prices if its known to the public (Desai and Dharmapala, 2006). According to Frank et al. (2009), when the fraudulent taxation of the company is found by the examination and taken through unlawful means, the company must get sanction from the tax authorities. At the end, the company bears other costs such as reputational costs and political costs (Hanlon and Slemrod 2009). The company's falling reputation and decreasing stock prices are caused by investors' negative perceptions of the company, as it indicates the existence of a rent extraction action by corporate managers that can harms shareholders (Desai and Dharmapala 2006).

\subsection{Tax Avoidance and Cash Holdings}

In contrast to the traditional theory that argues tax avoidance finally benefits the owners of the company, in the context of agency theory, it is clear that tax avoidance is an opportunistic behaviour of managers that benefits their own. To cover this opportunistic behaviour, managers attempts to limit some firm specific information (Kim et al. 2010). This exacerbates the asymmetric information between agent and owners which then causes company's asset transferred to the agent (Dhaliwal et al. 2011). In this regards, the most liquid asset namely cash 
is predicted to be the assets that mostly transferred or wasted by the agent, as argued by Dhaliwal et al. (2011) that while tax savings due to tax avoidance may benefit companies by increasing the cash flows, this condition may be inverted as tax avoidance facilitate managers to do more opportunistic behaviours and therefore cause more harm to the owner of the company.

Based on discussion above, the hypothesis of this study is as follows:

\section{$\mathrm{H}_{1}$ : Tax avoidance affects negatively to company's cash holdings}

\section{Research Methodology}

\subsection{Overview}

Triggered by Dhaliwal et al. (2011) which found that tax avoidance is able to facilitate managers in transferring resources i.e. company's cash, this research attempts to answer how is the influence of tax avoidance to the level of cash holdings in public companies. This research takes Indonesia as a background of the study as it is interesting to find evidence from one of developing countries which currently the regime applied tax amnesty. Since tax avoidance requires more confidential information and found as a tool for managers to perform managerial extraction and the nature of cash which is a very liquid asset and very easy to be converted by managers, this research attempts to examine the effect of tax avoidance on cash held by companies in public companies of Indonesia. Having longer research horizon, this study contributes to literature of tax and corporate finance as so far there is only one similar study found in Indonesia which is only based on limited cross-section data.

\subsection{Research Method}

This research is a quantitative study using secondary data which is collected from company's audited financial statements. The sample is all public companies in Indonesia listed on the Indonesia Stock Exchange with some exceptions to certain sectors due to different tax regulations such as application of final tax i.e. property, real estate, and construction sectors. This study also excludes more regulated industry i.e. financial companies. The design of this research is data panel analysis with periods from 2009-2016. Table 1 depicts the sample selection. 
Table 1. Sample Selection Method

\begin{tabular}{|c|l|c|}
\hline Number & \multicolumn{1}{|c|}{ Criteria } & $\begin{array}{c}\text { Number of } \\
\text { Companies }\end{array}$ \\
\hline 1. & Companies registered in BEI period 2009-2016 & 540 \\
\hline 2. & $\begin{array}{l}\text { Companies that belong to the financial sector } \\
(92)\end{array}$ & $(61)$ \\
\hline 3. & $\begin{array}{l}\text { Companies belonging to the property, real estate, } \\
\text { and construction sectors }\end{array}$ & $(114)$ \\
\hline 4. & $\begin{array}{l}\text { Companies that do not have complete audited } \\
\text { Annual Financial Statement data }\end{array}$ & $(175)$ \\
\hline 5. & $\begin{array}{l}\text { Companies that have experienced pre-tax loss } \\
\text { during 2009-2016 }\end{array}$ & $(26)$ \\
\hline 6 & $\begin{array}{l}\text { Companies that are undergoing tax refund during } \\
\text { 2009-2016 }\end{array}$ & 46 \\
\hline 7. & $\begin{array}{l}\text { Companies with Cash Effective Tax Rate } \\
\text { (CETR) values }>1\end{array}$ \\
\hline Number of Samples & 368 \\
\hline Number of Observations & $(26)$ \\
\hline
\end{tabular}

\subsection{Data Analysis}

This study adopts the model of Dhaliwal et al. (2011) which was originally developed by Opler et al. (1999):

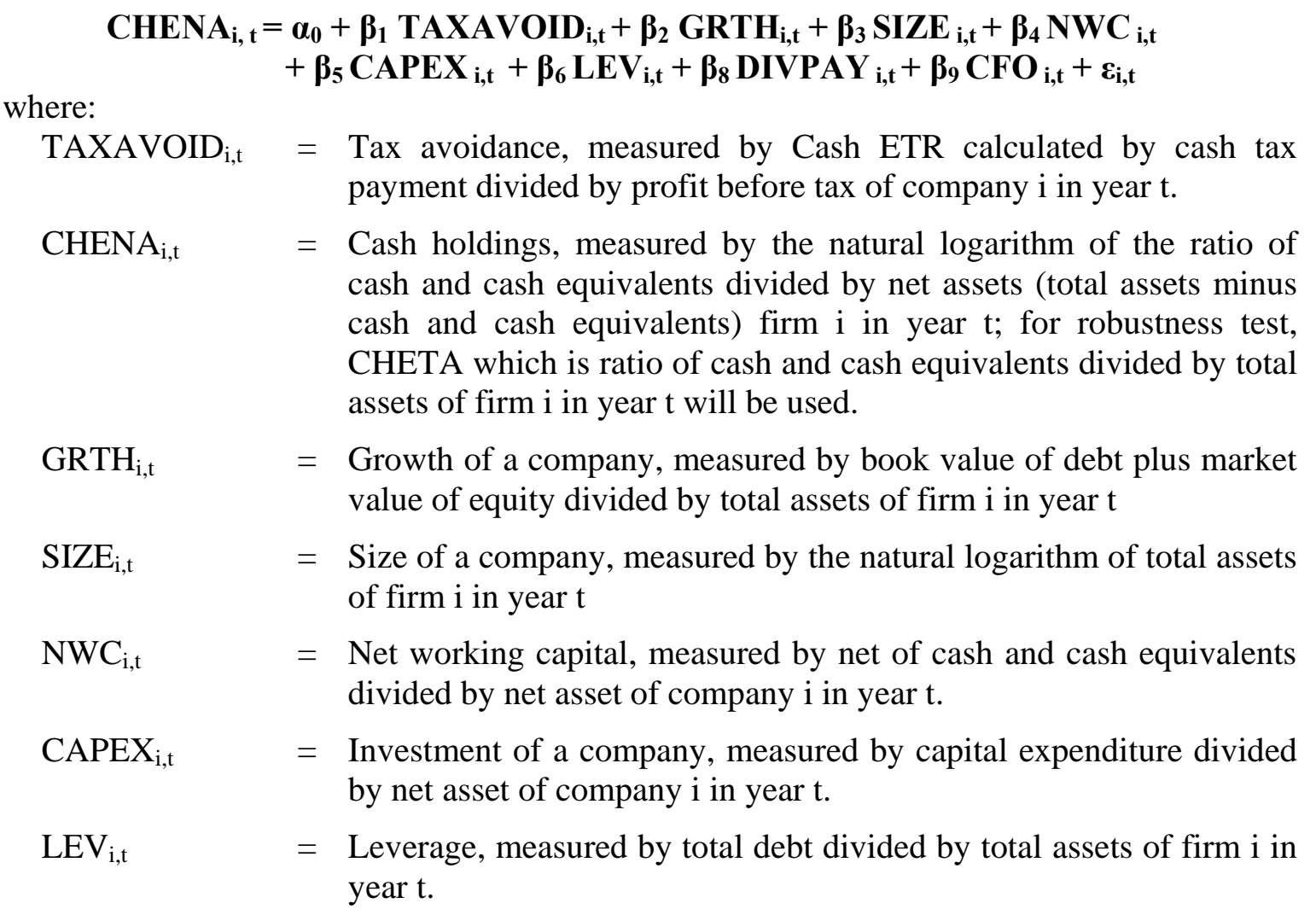


Kurniawan \& Nuryanah | The Effect of Corporate Tax Avoidance on the Level of Corporate Cash Holdings
DIVPAY $_{\mathrm{i}, \mathrm{t}} \quad=$ Dividend policy, measured by a dummy variable score of 1 if the company distributes a dividend score of 0 otherwise.
$\mathrm{CFO}_{\mathrm{i}, \mathrm{t}} \quad=$ Cash flows of a company, measured by cash flows from operating activities divided by net asset of company $\mathrm{i}$ in year $\mathrm{t}$.

\section{Results}

\subsection{Outlier Test}

Based on Table 2 below, it can be seen that all data variables have a value of p-value $<0.05$, it means data is not normally distributed, therefore the data needs to be winsorized.

Table 2. Shapiro-Wilk Test Results

\begin{tabular}{|c|c|c|c|c|c|}
\hline Variables & Observation & $\mathbf{W}$ & $\mathbf{V}$ & $\mathbf{z}$ & Prob $>\mathbf{z}$ \\
\hline CHENA & 368 & 0.73867 & 66.775 & 9.958 & 0.00000 \\
\hline CHETA & 368 & 0.89379 & 27.139 & 7.824 & 0.00000 \\
\hline TAXAVOID & 368 & 0.88300 & 29.895 & 8.053 & 0.00000 \\
\hline GRTH & 368 & 0.78675 & 54.489 & 9.476 & 0.00000 \\
\hline SIZE & 368 & 0.50854 & 125.578 & 11.455 & 0.00000 \\
\hline NWC & 368 & 0.98364 & 4.181 & 3.391 & 0.00035 \\
\hline CAPEX & 368 & 0.9215 & 20.059 & 7.108 & 0.00000 \\
\hline LEV & 368 & 0.94805 & 13.275 & 6.129 & 0.00000 \\
\hline DIVDUMMY & 368 & 0.97109 & 7.388 & 4.74 & 0.00000 \\
\hline OCF & 368 & 0.78564 & 54.773 & 9.488 & 0.00000 \\
\hline
\end{tabular}

\subsection{Descriptive Statistics Analysis}

Table 3. Descriptive Statistics (after Winsorization)

\begin{tabular}{|c|c|c|c|c|c|}
\hline Variables & Observation & Mean & Std. Dev. & Min & Max \\
\hline CHENA & 368 & 0.1850624 & 0.1820081 & 0.008029 & 0.9561303 \\
\hline CHETA & 368 & 0.1399056 & 0.108164 & 0.007965 & 0.4887866 \\
\hline TAXAVOID & 368 & 0.3164299 & 0.1671257 & 0.05713 & 0.9668318 \\
\hline GRTH & 368 & 2.091398 & 1.429452 & 0.630335 & 8.781985 \\
\hline SIZE & 368 & 17700000.00 & 35400000.00 & 135849.50 & 214000000.00 \\
\hline NWC & 368 & 0.1286213 & 0.187847 & -0.279723 & 0.5414513 \\
\hline CAPEX & 368 & -0.0746092 & 0.0529155 & -0.233458 & -0.005586 \\
\hline LEV & 368 & 0.202198 & 0.1456816 & 0.001577 & 0.5972779 \\
\hline DIVDUMMY & 368 & 0.8722826 & 0.3342293 & 0 & 1 \\
\hline OCF & 368 & 0.1262191 & 0.0778975 & -0.0130001 & 0.4202932 \\
\hline
\end{tabular}


Table 3. shows descriptive statistics of this study. Cash holdings is proxied by CHENA (the natural logarithm of the ratio of cash and cash equivalents to net assets, where net assets represent total assets minus cash and cash equivalents) and CHETA (cash and cash equivalents to total assets). The figure of CHENA shows that on average the companies have cash totaling $18.51 \%$ of net assets (with no cash and cash equivalents). A company that has the smallest CHENA ratio is PT. Tiga Pilar Sejahtera Food Tbk which is $0.8 \%$ while the highest is PT Bukit Asam (Persero) Tbk with 96\%. The figure of CHETA is $14 \%$ of total assets owned. The company with the smallest CHETA ratio is PT Arwana Citramulia Tbk which is $0.8 \%$ while the largest CHETA ratio is PT Bukit Asam (Persero) Tbk with a value of 49\%. Then the average rate of tax avoidance of the sample company is $32 \%$, with range $0 \%$ to $100 \%$, it can be considered that the level of tax avoidance of companies is quite high in Indonesia.

A growth opportunity denoted by GRTH is $209.13 \%$ meaning that the sample companies in this study have a high growth opportunity because the value has already exceeded $100 \%$ which means the sample company has a market value greater than its asset value which is based on book value. Companies with the lowest growth opportunity value are PT Colorpak Indonesia Tbk, PT Ekadharma International Tbk, PT Gema Grahasarana Tbk, PT Jakarta International Hotels \& Development Tbk, PT KMI Wire and Cable Tbk and PT Multi Indocitra Tbk with a value of $63.03 \%$. Then the companies with the highest growth opportunity value are PT Surya Citra Media Tbk, PT Kalbe Farma Tbk, PT Ace Hardware Indonesia Tbk, PT Adaro Energy Tbk, and PT Sumber Alfaria Trijaya Tbk, with the value of $878.19 \%$. The size of the company denoted by SIZE having average is Rp 17.7 trillion, with the lowest value of Rp 135.8 billion is PT Pyridam Farma Tbk while the largest is PT Astra International Tbk with total assets of Rp 214 trillion. Net working capital denoted by NWC shows that on average $13 \%$ of non-cash current assets can be used as a source of liquidation by the sample company in the short term. In regards to the average of net asset which is Rp15.3 trillion, it can be known that Rp 1.9 trillion of net working capital can be converted into cash in the near term. Then the smallest net working capital value is $-28 \%$; this happens because there is a sample company whose total liabilities smoothly exceeds the total current assets, which is PT Jasa Marga (Persero) Tbk while the largest net working capital value is $54.14 \%$ owned by PT MultiIndocitra Tbk.

Capital expenditure denoted by CAPEX shows that on average capital expenditure of the sample companies is $-7.4 \%$. This figure shows that the sale of the company's fixed assets is greater than the amount of its fixed asset purchase. The minimum value of the capital expenditure is $-23.3 \%$ owned by PT Jasuindo Tiga Perkasa Tbk means the company sold 23.3\% of its fixed assets from net assets. On the other hand, the maximum value of capital expenditure is $-0.5 \%$ owned by PT Trikomsel Oke Tbk. Then, leverage denoted by LEV shows that on average leverage of the sample company is $20.2 \%$; this indicates that the sample company has 20.2\% leverage to its total assets. With the average total assets of the sample companies of Rp 17.7 trillion, the average leverage of the sample companies in rupiah is Rp 35.7 trillion. The lowest LEV value is owned by PT Bukit Asam (Persero) Tbk of $0.15 \%$ while the highest LEV is PT Trikomsel Oke Tbk which is 60\%.

Dividend payment denoted by DIVDUMMY shows that on average only $87.2 \%$ of the sample companies pay dividends. It also shows that during the research periods most companies make dividend payments during the study period. The other control variable which is cash flow of the operating activities denoted by OCF shows that on average cash flow from the company's sample operation activity is 13\%. This figure means that with average net assets of Rp 15.3 trillion, the average total cash flows from operating activities in rupiah currency units amounted 
to Rp 1.9 trillion. The minimum value of OCF variable is owned by PT Kalbe Farma Tbk ($1.3 \%$ ) while the maximum value is $42 \%$ owned by PT Bukit Asam (Persero) Tbk.

\subsection{Selection of Panel Data Model}

This research is based on panel data where the determination of the model is done through three stages. The first test is Chow test to determine whether the model is Pooled Least Square (PLS) model or Fixed Effect (FE). The next test is Breusch-Pagan Test Lagrangian Multiplier (BPLM) to determine whether the model is PLS model or Random Effect (RE). The final test is Hausman test to determine whether the data fit for FE or RE models. Based on the tests, the best model is random effect (for proxy CHENA) while for the robustness model (using proxy CHETA) is a fixed effect model.

\subsection{Classical Assumption Test Results}

Table 4. Results of Multicollinearity Test

\begin{tabular}{|c|c|c|}
\hline Variables & VIF & $\mathbf{1 / V I F}$ \\
\hline SIZE & 23.06 & 0.043367 \\
\hline DIVDUMMY & 8.99 & 0.111280 \\
\hline OCF & 4.61 & 0.216940 \\
\hline TAXAVOID & 4.58 & 0.218307 \\
\hline GRTH & 4.52 & 0.22110 \\
\hline CAPEX & 3.69 & 0.271361 \\
\hline LEV & 3.60 & 0.27750 \\
\hline NWC & 1.70 & 0.587926 \\
\hline Mean VIF & 6.84 & \\
\hline
\end{tabular}

This study uses a linear regression which must qualify Best Linear Unbiased Estmates (BLUE). Three stages of testing from the classical assumption were conducted which are multicolinearity test, heterokedastisity test, and autocorrelation test. Table 4 shows that the average value of VIF is 6.84 which means less than 10. Hence, the assumption of multicollinearity is not violated by the variables.

The second BLUE test which is heterocedasticity test applies only to PLS and Fixed Effect panel data models whereas the Random Effect model of this assumption is not violated because the test will use Generalized Least Square (GLS). Therefore, the heterocedasticity test was conducted only for the second model, robustness model using CHETA. The result shows that $\operatorname{chi}^{2}(46)=2732.81$ and Prob $>$ chi2 $=0.0000$. As the value of Prob $>$ chi2 less than 0.05 , the second model has heterocedasticity problem.

The last classical BLUE assumption requirement is an autocorrelation which ensures that observation data have no time-to-moment relationship. Wooldridge test was conducted to ascertain whether the model has an autocorrelation problem. The basis for determining the violation of this assumption is seen from Prob> F if the value is lower than 0.05 then there is a violation of this assumption. This test was conducted only on the second model because the assumption is still the same, that is the first model using Random Effect autocorrelation assumption is also not violated due to using GLS. The results of this assumption test are $\mathrm{F}(1$, 45) $=21.893$ and Prob $>F=0.0000$ meaning that for the second model has an autocorrelation 
problem. The second model, however, is regressed with DriscollKraay standard errors Fixed Effect to solve the autocorrelation problem.

\subsection{Simultaneous Effect Test (F-test) and (Chi ${ }^{2}$-test)}

Table 5 shows that for the first model using a random effect the $\mathrm{Chi}^{2}$ value equals to 0.0000 which is less than p-value 0.05; this means that independent variables together are simultaneously able to influence variable dependent. Similar to the first model, the second research model that uses fixed effect also gives the value Prob> F for 0.0000 as shown in Table 6.

The first model using random effect has R-Squared 0.2856 meaning that $28.5 \%$ of the independent variables can explain cash holdings of a company while the second model using fixed effect shows R-Squared much higher which is 0.3276 meaning that $33 \%$ independent variables can explain cash holdings of a company.

\subsection{Analysis of Hypothesis Testing Results}

Table 5. Regression Test Results First Model with Random Effect

\begin{tabular}{|c|c|c|c|c|c|c|}
\hline CHENA & Coef. & Std. Err. & $\mathrm{Z}$ & $\mathrm{P}>|\mathrm{z}|$ & \multicolumn{2}{|c|}{ [95\% Conf. Interval] } \\
\hline TAXAVOID & -0.1168356 & 0.19907 & -0.59 & 0.557 & -0.5069959 & 0.27332 \\
\hline GRTH & -0.0133226 & 0.03381 & -0.39 & 0.694 & -0.0795839 & 0.05294 \\
\hline SIZE & 0.0606593 & 0.04911 & 1.24 & 0.217 & -0.0355897 & 0.15691 \\
\hline NWC & -1.39055 & 0.32971 & -4.22 & $* * * 0.000$ & -2.036775 & -0.7443 \\
\hline CAPEX & -0.156941 & 0.67638 & -0.23 & 0.817 & -1.482622 & 1.16874 \\
\hline LEV & -3.100857 & 0.41585 & -7.46 & $* * * 0.000$ & -3.915901 & -2.2858 \\
\hline DIVDUMMY & 0.0397748 & 0.10984 & 0.36 & 0.717 & -0.175512 & 0.25506 \\
\hline OCF & 3.155909 & 0.48635 & 6.49 & $* * * 0.000$ & 2.202674 & 4.10914 \\
\hline CONS & -2.661119 & 0.77865 & -3.42 & 0.001 & -4.187242 & -1.135 \\
\hline $\begin{array}{c}\text { Number of } \\
\text { Obs. }\end{array}$ & 368 & \multirow{4}{*}{\multicolumn{5}{|c|}{$\begin{array}{l}\text { Description: CHENA = natural logarithm of the ratio of } \\
\text { cash and cash equivalents to net assets in which net } \\
\text { assets represent total assets minus cash and cash } \\
\text { equivalents; CHETA = cash and cash equivalents to total } \\
\text { assets; TAXAVOID = measured by using a Cash } \\
\text { Effective Tax Rate wherein the cash in taxes divided by } \\
\text { profit before tax; GRTH = using Tobin's Q ratio; SIZE = } \\
\text { natural logarithm of total assets; NWC = Ratio of net } \\
\text { working capital with net assets; CAPEX = ratio of capital } \\
\text { expenditures to net assets; LEV = ratio of total liabilities } \\
\text { to total assets; DIVDUMMY = is a dummy variable of } \\
\text { dividend payment "1" if it pays "0" otherwise; OCF = } \\
\text { cash flow ratio from operating activities to net assets. } \\
\text { Signs *, **, *** signify significance at successive levels } \\
\text { of } 10 \%, 5 \% \text {, and } 1 \% \text {. }\end{array}$}} \\
\hline Wald chi2(8) & 145.07 & & & & & \\
\hline Prob > chi2 & 0 & & & & & \\
\hline $\begin{array}{l}\text { R-Squared } \\
\text { (within) }\end{array}$ & 0.2856 & & & & & \\
\hline
\end{tabular}


Table 5 shows further that tax avoidance (TAXAVOID) has a coefficient and p-value of 0.1168 and 0.557 respectively meaning not significant to cash holdings. The table also presents that many control variables are not significant to cash holding policy of a company, which are growth opportunities (GRTH) with p-value of 0.694, firm size (SIZE) with p-value value of 0.217, capital expenditure (CAPEX) with p-value of 0.817 , and dividend payment (DIVDUMMY) with p-value of 0.717.

Control variables which are significant explaining the cash holdings policy are explained as follows. Net working capital (NWC) has a coefficient and p-value of -1.39055 and 0.000 (significant at $1 \%$ level) respectively. Hence, it can be said that net working capital variable has a significant negative effect to the company's cash holdings, proxied by CHENA. Then, leverage (LEV) has a coefficient and p-value equals to -3.100857 and 0.000 (significant at level 1\%). Finally, the cash flow from operating activities (OCF) shows a coefficient and p-value value of 3.155909 and 0.000 respectively bringing a conclusion that cash flow from operating activities has a significant positive relationship.

Table 6 below shows a similar conclusion to the first model for the relationship between tax avoidance and cash holdings policy as the results is insignificant. Some control variables are also not significant, which are growth opportunities (GRTH), firm size (SIZE), capital expenditure (CAPEX), and dividend payout (DIVDUMMY).

Table 6. Second Regression Model Results (with Driscoll-Kraay standard errors Fixed Effect)

\begin{tabular}{|c|c|c|c|c|c|c|}
\hline CHETA & Coef. & Std. Err. & $\mathrm{t}$ & $\mathrm{P}>|\mathrm{t}|$ & \multicolumn{2}{|c|}{ [95\% Conf. Interval] } \\
\hline TAXAVOID & -0.0131882 & 0.01766 & -0.75 & 0.479 & -0.054945 & 0.0285687 \\
\hline GRTH & -0.005053 & 0.00269 & -1.88 & 0.103 & -0.011419 & 0.001314 \\
\hline SIZE & -0.009275 & 0.00316 & -2.94 & $* * 0.022$ & -0.016736 & -0.0018144 \\
\hline NWC & -0.112636 & 0.04005 & -2.81 & $* * 0.026$ & -0.20733 & -0.0179419 \\
\hline CAPEX & -0.059343 & 0.05836 & -1.02 & 0.343 & -0.197338 & 0.0786515 \\
\hline LEV & -0.308229 & 0.02339 & -13.18 & $* * * 0.000$ & -0.363535 & -0.2529222 \\
\hline DIVDUMMY & 0.0014259 & 0.00638 & 0.22 & 0.830 & -0.01367 & 0.016522 \\
\hline OCF & 0.3769583 & 0.0461 & 8.18 & $* * * 0.000$ & 0.267958 & 0.4859587 \\
\hline CONS & 0.3202667 & 0.06506 & 4.92 & 0.002 & 0.1664141 & 0.4741194 \\
\hline $\begin{array}{c}\text { Number of } \\
\text { Obs. }\end{array}$ & 368 & \multirow{4}{*}{\multicolumn{5}{|c|}{$\begin{array}{l}\text { Description: CHENA = natural logarithm of the ratio of } \\
\text { cash and cash equivalents to net assets in which net assets } \\
\text { represent total assets minus cash and cash equivalents; } \\
\text { CHETA = cash and cash equivalents to total assets; } \\
\text { TAXAVOID = measured by using a Cash Effective Tax } \\
\text { Rate wherein the cash in taxes divided by profit before tax; } \\
\text { GRTH = using Tobin's Q ratio; SIZE = natural logarithm } \\
\text { of total assets; NWC = Ratio of net working capital with } \\
\text { net assets; CAPEX = ratio of capital expenditures to net } \\
\text { assets; LEV = ratio of total liabilities to total assets; } \\
\text { DIVDUMMY = is a dummy variable of dividend payment } \\
\text { "1" if it pays " } 0 \text { " otherwise; OCF = cash flow ratio from }\end{array}$}} \\
\hline $\mathrm{F}(8,7)$ & 837.74 & & & & & \\
\hline Prob > F & 0.0000 & & & & & \\
\hline R-squared & 0.3276 & & & & & \\
\hline
\end{tabular}




\begin{tabular}{|l|l|l|} 
(within) & $\begin{array}{l}\text { operating activities to net assets. Signs } *, * *, * * * \text { signify } \\
\text { significance at successive levels of } 10 \%, 5 \%, \text { and } 1 \% .\end{array}$ \\
\hline
\end{tabular}

The other control variables are significant namely net working capital (NWC), leverage (LEV) and cash flow from operating (OCF). Net working capital is significant (at alpha 5\% level) with a coefficient of -0.112636 meaning that every $1 \%$ increase in the net working capital variable will decrease the company's cash holdings by $11.26 \%$. Then, leverage (LEV) has a coefficient and p-value value of -0.308229 and 0.000 (significant at alpha $1 \%$ ) respectively. Operating cash flows is also significant with a coefficient of 0.000 .

\section{Discussion}

Due to tax avoidance allegedly able to facilitate managers to transfer resources of the company, this research attempted to answer how tax avoidance affects ownership of cash of public company in Indonesia. Based on the results above, it is concluded that the findings of the study are similar to Melinda (2013) that in the context of Indonesia there is no evidence that tax avoidance activities influence cash holdings of a company. The corporate policy of cash holdings can be explained only by control variables of net working capital, leverage and operating cash flows. As the study found non-significant growth value to cash holdings, the result is consistent with the anecdote that firms with small growth opportunities have more cash than firms with high growth opportunities because they are overseen by investors. The other controlling variables namely capital expenditure, growth, size and dividend policy of a company are neither able to explain the amount of cash held by the company.

This study which cannot find the effect of tax avoidance on the level of cash of the company provides an insight that agency theory in the context of tax avoidance and corporate cash holdings in developing countries such as Indonesia needs to be explored further as the agency conflict in Indonesia as a developing country is different to developed countries. Found by Claessens et al. (2000), the agency conflict in Indonesia is more principal-principal conflicts, not principal-agent conflicts.

\section{Conclusion}

The objective of this study is to examine the relationship between the amount of cash held by a company and tax avoidance. Based on eight-year research horizon with 368 observations collected from Indonesian public companies, nevertheless, this study is unable to find this relationship. The findings of this study still cannot find evidence that tax avoidance has a significant effect on the level of firm cash holdings in Indonesian public companies, as found by previous studies in Indonesia. More comprehensive data and more proxies may improve the results.

\section{Acknowledgement}

The authors are grateful to Lukman Edwindra who has provided a source of data for this research. 
Kurniawan \& Nuryanah | The Effect of Corporate Tax Avoidance on the Level of Corporate Cash Holdings

\section{References}

Abdillah, F. (2013). Pengaruh Karakteristik Perusahaan dan Board Size terhadap Corporate Cash Holding, Unpublished Bachelor Thesis, Depok: Universitas Indonesia

Avi-Yonah, R.S. (2008). “Corporate social responsibility and strategic tax behavior” in Tax and corporate governance, pp. 183-198, Springer, Berlin, Heidelberg.

Bates, T. W., Kahle, K. M., \& Stulz, R. M. (2009). Why Do U.S. Firms Hold So Much More Cash than They Used To? The Journal of Finance, pp. 1985-2021 https://doi.org/10.1111/j.1540-6261.2009.01492.x

Boubaker, S., Derouiche, I., \& Nguyen, D. K. (2013). Does the board of directors affect cash holdings? A study of French listed firms. Springer, pp. 342-370.

Chen, S., Chen, X., Cheng, Q., \& Shevlin, T. (2010). Are family firms more tax aggressive than non-family firms?. Journal of Financial Economics, 95, pp. 41-61. https://doi.org/10.1016/i.jineco.2009.02.003

Chen, Y., Huang, S., Pereira, R., Wang, J. (2011), Corporate Tax Avoidance and Firm Opacity, Unpublished Working Paper University of Missouri.

Chen, X., Hu, N., Wang, X. and Tang, X. (2014). Tax avoidance and firm value: evidence from China. Nankai Business Review International, 5(1), pp. 25-42. https://doi.org/10.1108/NBRI10-2013-0037

Claessens, S., Djankov, S. and Lang, L.H. (2000). The separation of ownership and control in East Asian corporations. Journal of financial Economics, 58(1), pp.81-112. https://doi.org/10.1016/S0304-405X(00)00067-2

Desai, M. A., Dharmapala, D. (2006). Earnings Management and Corporate Tax Shelters, Unpublished Working Paper Harvard Business School.

Desai, M., Dharmapala, S. (2008). Tax and Corporate Governance: an Economic Approach. In Schon, W., (Ed.). Tax and Corporate Governance. Berlin: Springer-Verlag, 13 https://doi.org/10.1007/978-3-540-77276-7 3

Dhaliwal, D. S., Huang, S. X., Moser, W. J., \& Pereira, R. (2011). Corporate tax avoidance and the level and valuation of firm cash holdings. Available at SSRN: https://ssrn.com/abstract=1800140 or http://dx.doi.org/10.2139/ssrn.1800140

Dittmar, A., Mahrt-Smith, J., and Servaes, H. (2003). International Corporate Governance and Corporate Cash Holdings. Journal of Financial and Quantitative Analysis, 38(1), pp.111133 https://doi.org/10.2307/4126766

Dyreng, S., M. Hanlon, dan E.L. Maydew. (2008). Long-run corporate tax avoidance. The Accounting Review, 83 (2), pp. 61-82. https://doi.org/10.2308/accr.2008.83.1.61

Ferreira, M.A., Vilela, A.S. (2004). Why do firms hold cash? Evidence from EMU countries. European Financial Management, 10(2), pp. 295-319. https://doi.org/10.1111/i.13547798.2004.00251.x

Godfrey et al. (2010). Accounting Theory. $7^{\text {th }}$ Edition . John Wiley \& Sons : Australia. 
Guenther, D. A., Matsunaga, S. R., and Williams, B. M. (2013). Tax avoidance, tax aggressiveness, tax risk and firm risk. Unpublished paper.

Hanlon, M., \& Heitzman, S. (2010). A review of tax research. Journal of Accounting and Economics, 50(2), pp. 127-178. https://doi.org/10.1016/j.jacceco.2010.09.002

Hanlon, M., et al. (2017). The taxman cometh: Does tax uncertainty affect corporate cash holdings?, Review of Accounting Studies, 22(3), pp. 1198-1228. https://doi.org/10.1007/s11142-017-9398-y

Irawan, Hendra P. dan Aria Farahmita. (2014). Pengaruh Kompensasi Manajemen dan Corporate Governance Terhadap Manajemen Pajak Perusahaan. Jakarta. Universitas Indonesia.

Ismiyanti, F. dan Hanafi, M. (2004). Struktur Kepemilikan, Risiko, dan Kebijakan Keuangan: Analisis Persamaan Simultan. Jurnal Ekonomi dan Bisnis Indonesia. Vol. 19, No. 2, pp. 176-196.

Jensen, M., Meckling, W. (1976). Theory of the Firm: Managerial Behavior, Agency Costs and Ownership Structure. Journal of Financial Economics, 3, pp. 305-360. https://doi.org/10.1016/0304-405X(76)90026-X

Jensen, M. (1986). Agency costs of free cash flow, corporate finance and takeovers. American Economic Review, 76, pp. 323-329.

Kariuki, S. N., Namusonge, G. S., \& Orwa, G. O. (2015). Determinants of Corporate Cash Holdings: Evidence from Private Manufacturing Firms in Kenya. International Journal of Advanced Research in Management and Social Sciences, pp. 15-33.

Keynes, J. M. (1936). The General Theory of Employment, Interest and Money. Palgrave Macmilan.

Khoala, A. (2013). Does Corporate Governance affect tax planning? Evidence from American companies. International Journal of Advanced Research, 1 (10), pp. 864-873.

Kim, J.B., Li, Y. and Zhang, L., 2011. Corporate tax avoidance and stock price crash risk: Firmlevel analysis. Journal of Financial Economics, $100 \quad$ (3), pp. 639-662. https://doi.org/10.1016/i.jineco.2010.07.007

Kuan, T.-H., Li, C.-S., \& Chu, S.-H. (2011). Cash Holdings and Corporate Governance in Family-Controlled Firms. Journal of Business Research, pp. 757-764. https://doi.org/10.1016/j.jbusres.2010.07.004

Kurniasih, Tommy dan Maria M. Ratna Sari. (2013). Pengaruh Return on Assets, Leverage, Corporate Governance, Ukuran Perusahaan dan Kompensasi Rugi Fiskal pada Tax Avoidance. Buletin Studi Ekonomi. ISSN 1410-4628, Volume 18, No. 1, Februari 2013.

Kusnadi, Y., 2011. Do corporate governance mechanisms matter for cash holdings and firm value?. Pacific-Basin Finance Journal, 19(5), pp. 554-570. https://doi.org/10.1016/i.pacfin.2011.04.002

Lian, Y., Sepehri, M., \& Foley, M. (2011). Corporate Cash Holdings and Financial Crisis: An Empirical Study of Chinese Companies. European Business Review, pp. 112-124.

Lietz, G. M. (2013). Tax avoidance vs. tax aggressiveness: A unifying conceptual framework. Browser Download This Paper. 
Kurniawan \& Nuryanah | The Effect of Corporate Tax Avoidance on the Level of Corporate Cash Holdings

Melinda, Corry. (2013). Analisis Pengaruh Pengaruh Praktik Penghindaran Pajak Terhadap Jumlah Kas yang Dipegang Perusahaan dan Penilaian Perusahaan, Unpublished Bachelor Thesis, Depok: Universitas Indonesia

Myers, S., Raghuram, R. (1998). The Paradox of Liquidity, Unpublished Working Paper Center for Research in Security Prices, Graduate School of Business, University of Chicago.

Ogundipe, S. E., Salawu, R. O., \& Ogundipe, L. O. (2012). The Determinants of Corporate Cash Holdings in Nigeria: Evidence from General Method of Moments (GMM). International Journal of Social, Behavioral, Economic, Business, and Industrial Engineering, pp. 152158.

Opler, T., Pinkowitz, L., Stulz, R., \& Williamson, R. (1999). The Determinants and Implications of Corporate Cash Holdings. Journal of Financial Economics, 52(1), pp. 3-46. https://doi.org/10.1016/S0304-405X(99)00003-3

Ozkan, A., \& Ozkan, N. (2004). Corporate Cash Holdings: An Empirical Investigation of UK Companies. Journal of Banking \& Finance, 28 (9), pp. 2103-2134. https://doi.org/10.1016/i.jbankfin.2003.08.003

Pohan, Chairil Anwar. (2015). Manajemen Perpajakan. Cetakan Ketiga. Jakarta: PT Gramedia Pustaka Utama.

Prebble, Z. M., \& Prebble, J. (2010). The morality of tax avoidance. Creighton Law Review, 43 (3), pp. 693-745.

Rizwan, M. F., \& Javed, T. (2011). Determinants of Corporate Cash Holdings: Evidence from Pakistani Corporate Sector. Economics, Management, and Financial Markets, 6 (1), pp. 344-358.

Ross, S., Westerfield, R., \& Jordan, B. (2012). Fundamentals of Corporate Finance, 10th edition. McGraw-Hill Education.

Sandy, Syeldila, Niki Lukviarman. (2015). Pengaruh corporate governance terhadap tax avoidance: Studi empiris pada perusahaan manufaktur di Bursa Efek Indonesia. Jurnal Akuntansi dan Auditing Indonesia. https://doi.org/10.20885/jaai.vol19.iss2.art1

Santana, S.L.L. and Rezende, A.J. (2016). Corporate tax avoidance and firm value: evidence from Brazil. Available at

SSRN: https://ssrn.com/abstract=2803993 or http://dx.doi.org/10.2139/ssrn.2803993

Santoso, Iman, Ning Rahayu. (2013). Corporate tax management. Jakarta: Ortax.

Saputra M. Fajri, Dandes R., Novia R. (2015). Pengaruh corporate governance, profitabilitas dan karakter eksekutif terhadap tax avoidance pada perusahaan yang terdaftar di BEI. Jurnal Akuntansi dan Auditing Indonesia, 19 (2), pp. 85-98.

Sekaran, U., dan R. Bougie. (2013). Research Method for Business. A Skill Building Approach. John Wiley and Sons, Ltd.

Shah, A. (2011). The Corporate Cash Holdings: Determinants and Implications. African Journal of Business Management, Vol. 5, No. 34, pp. 12939-12950.

Solomon, J. (2007). Corporate governance and accountability. $2^{\text {nd }}$ ed. The Atrium, West Sussex : John Wiley\&Sons,Ltd. 
Wang, X. (2010). Tax avoidance, corporate transparency, and firm value (Doctoral dissertation).

Wang, Xiaohang. (2011), Tax Avoidance, Corporate Transparency, and Firm Value, American Accounting Association Annual Meeting - Tax Concurrent Sessions. Available at SSRN: https://ssrn.com/abstract=1904046 or http://dx.doi.org/10.2139/ssrn.1904046

Wardani, D.K. 2008. Pengaruh corporate governance terhadap kinerja perusahaan di Indonesia. Yogyakarta: Universitas Islam Indonesia.

Wasiuzzaman, S. (2014). Analysis of Corporate Cash Holdings of Firms in Malaysia. Journal of Asia Business Studies, 8 (2), pp.118-135. https://doi.org/10.1108/JABS-10-2012-0048

Wilson, R. J. (2009). An examination of corporate tax shelter participants. The Accounting Review, 84(3), 969-99 https://doi.org/10.2308/accr.2009.84.3.969 